\title{
CORRESPONDENCE
}

\section{GLACIAL DRIFTS}

SrR,-Dr. Anderson plunges blindly on, unable to see the dangers ahead. I will point them out, but must first deal with his reply.

He desires to confine himself to his Roslin sand-pits. Unfortunately, he attempted to explain what he saw there, and by invoking a profound, and pre-till, freezing of the sand, raised a jinn quite beyond his control-a tundra condition which would affect many thousands of square miles, so that, whatever his wishes, he cannot ignore like sections within the area covered by "Northern Glacial Drifts". Incidentally, he need have no qualms about applying that paper to Scotland : long years of field-work there leave me in no doubt on that score. In time, he will find in the Central Valley all that we have in Northern England, with some interesting additions.

What are the "proofs" that the till is later than the sands? The manner of its superposition, its infilling of the fissures, and that it can, on occasion, line an erosion hollow, are all points even more useful to myself. And what evidence is there for a pre-till freezing of the sands? None whatever that I can see. Surely these are ideas and no more, as are other orthodox notions, all disproved by the till contacts, and features within the sands, the silts, the laminated clays. As to the resistant power of frozen sand, how many glaciated sandstone sections of comparable size has he seen so utterly undisturbed as those sands at Roslin, let alone elsewhere?

Since the original account left much to be desired, he recently showed me his leading pit (Bilston), one of commonplace type, repeated again and again in Northern England. The allimportant till contact, sharp-cut as usual and with no trace of incorporation, showed, even at the first glance, a thin slice of till, 4 or 5 feet long, detached from the main mass above, and lying within the sands, whose current-bedding was unaffected. The drop was no more than 2 or 3 inches, but it was clear and unmistakable (cf. similar cases in the "Drifts" paper). How could that slice have got there, save as a fall from a roof of sheared-up till, during an undermelt of the ice-sheet? Until an equally reasonable explanation be found I must regard this as decisive evidence.

As the till-contact so strongly suggested a full " undermelt sequence", search was made at the bottom of the pit for the 
confirmation which would be given by a "silt zone". There it was, with its characteristic structures, unlike anything in normal sedimentation: they cannot be detailed here, but are useful additions to a forthcoming paper.

Now for the fissures in the sands: the original one had gone, but there were others of all sizes, notably one 7 or 8 inches across at the top, thence tapering gently to a fine point 8 or 9 feet below. With unbroken walls, it was packed with till throughout-in effect a trough-fault, as are all tundra frostwedges or cracks. Such things, common in waterlogged sands and gravels, start as expansion swellings under which, on thawing, cracks develop that, as fast as they form, are plugged by the local surface cover ; incessant repetition greatly extends the initial wedge. At Roslin the cover was till, thick enough ( 6 feet) to ensure that only unweathered material entered the cracks.

The final deduction is that, exactly as in Northern England, (I) a suite of drifts resulted from the continuous undermelt of a stagnant ice-sheet, wherein lay a sheared-up strip of till ; (2) there followed a post-Glacial tundra phase, marked by pronounced frost-wedging. A sequence of ideas, yes, but is it not the natural (I would say inevitable) resultant of the facts? The like can hardly be said for Dr. Anderson's sequence : this needs, before the advent of the till, (1) deeply frozen sands, of whose condition no evidence remains, (2) long fissures in those sands, open to the very bottom; unique features whose causation, I imagine, is unknown (even earthquake cracks would not serve). Then (3) advancing over all an ice-sheet whose till, frozen also, and in effect a conglomerate-rock, is rammed into the remotest crannies of those fissures, yet without breakdown of their walls, or sign of forward movement anywhere. Finally (4), still with everything hard frozen, he now has to say how that long slice of till got into the sands without disturbing them.

So much for the orthodox creed, when indulged in to the full. Clearly a heady wine, and potent . . . but not so good in the cold light of morning.

R. G. Garruthers.

High BARN,

STOCKSFIELD-ON-TyNE. 